ด

columns of psychoanalysis, met briefly with Freud in 1912, Moreno said, "I start where you leave off. . . . You analyze their dreams, give them the courage to dream again" (Marineau, 1989).

Psychodrama is an action method of psychotherapy, working in groups. The unique quality of training is that trainees participate in psychodrama using their own experience. Experimental work of 730 hours must be completed. This is challenging, so personal psychotherapy is mandatory.

Managing the pain of the human psyche, recognising trauma that presents as mental illness, acknowledging that the pain of living can be less bearable than the pain of dying - this is fundamental to psychiatry. Psychiatrists need and have empathy, perhaps too much. We need to be able to bear the most terrifying stories. Everyone has their own. We need resilience as well as empathy for this. If personal therapy can facilitate this it should be considered a recommended part of training and continuing professional development at all stages of our careers.
KIPPER, D. A. (1992) Psychodrama: Group psychotherapy through role playing. International Journal of Group Psychotherapy, 42 495-521.

MARINEAU, R. F. (1989) Jacob Levy Moreno, 1889-1974. London: Routledge.

Kristina Hofberg, Specialist Registrar, The Foundation NHS Trust, Corporation Street, Stafford; e-mail kristina.hofberg@virgin.net

\section{Group psychotherapy training}

Sir: The article by Hull and colleagues, 'Group psychotherapy: trainee's perspective' (Psychiatric Bulletin, September 2000, 24, 342-344) gives an interesting and informative account of their experience of group psychotherapy and its place in psychiatric training.

Trainees should also be aware of more formal training opportunities available to them. A number of introductory group courses are run in different centres around the UK under the auspices of the Institute of Group Analysis. They consist of both theoretical seminars and participation in small and large experimental groups. They provide at least three of Yalom's four components of a comprehensive group therapy training cited in the article: a personal group experience, observing an experienced conductor at work and an element of personal therapy (Yalom, 1995). The fourth, supervision of group work, can also often be arranged.

In addition, these courses provide a multi-disciplinary peer group. I would suggest that this greatly increases their value for training. It also highlights the comparative absence of multi-disciplinary learning in much of psychiatric training.

In addition to the route taken by Hull and colleagues, or perhaps in conjunction with it, trainees seeking experience of group psychotherapy should be aware of other avenues available to them.

YALOM, L. D. (1995) TheTheory and Practice of Group Psychotherapy (4th edn). NewYork: Basic Books.

Dan Beales, Locum Staff Grade, Shakespeare House, Ashworth Hospital Authority, Parkbourn Maghull, Merseyside L31 1HW

\section{the college}

\section{1: A Mind Odyssey}

Sculpture, Bhangra dance, film, playwriting, drama, literature, music and visual arts. These are just a few of the events at the Annual Meeting in July, which will launch 2001: A Mind Odyssey, the College's year-long celebration of the arts, the mind and psychiatry.

Highlights will include the inaugural concert by the College Music Society, conducted by a member of the College, Dr David Kingsley. The orchestra and choir will also perform Paean, a piece commissioned especially for the opening ceremony from composer Guy Woolfenden, Head of Music at the Royal Shakespeare Company for 37 years.

During the Annual Meeting there will be an opportunity to view some of the Bethlem Hospital's important art collection at a special exhibition in Central London. For those interested in 20th Century 'icons', the Director of the National Portrait Gallery will introduce the collections at a special reception in the galleries.

The College is working with a number of partners in the arts - the internationally renowned Courtauld Gallery and Royal Court Theatre - to create innovative programmes and new theatre. Films relating to psychiatry will be explored through a festival of films that wil premier at the Riverside Studios in West London. It is hoped to replicate this event around the country. Service users will have an opportunity to enter a College art competition. The winning entries will be shown at exhibitions in London and Cardiff. For all events by the College, see the calendar of events below.

2001: A Mind Odyssey is about participation. We hope the celebration's momentum will come from members around the country. Many ideas are currently being explored. Some of the innovative initiatives planned by members are listed below. We hope these will inspire you to organise an event in your area!

- Patients'art exhibition

- The history of psychiatry - an enactment

- Exhibition of psychiatrists'art

- Art exhibitions on mental health

- Music evenings

- Dance workshops and performance

- Arts and the mind - an event at the Birmingham Midlands Art Centre

- An evening of storytelling and ballads

- Poets and pints - poetry by psychiatrists

- Dramatherapy - a one woman show

- Contribution to the Hay Literary Festival

- Culinary treats for school children

\section{Calendar of College managed events}

\section{July 2001}

Events during the Annual Meeting, in London:

- StrathconaTheatre, a performance by actors with learning disabilities

- Music theatre production by College members

- Exhibition of works from the Bethlem Hospital Art Collection

- Reception at National Portrait Gallery

- College Music Society concert

- Indian music and dance

- Sculpture exhibition

- Arts workshops, talks and sessions

\section{September}

- Festival of Film at Riverside Studios, West London

- Courtauld Gallery art workshops: patients and staff from the Child \& Family Psychiatric Unit, Brent, Kensington, Chelsea \& Westminster Mental Health Trust

- Pottery Residency at Brent, Kensington, Chelsea and Westminster Mental Health Trust

\section{October}

- Opening of art competition for service users 